\title{
PENGARUH KOMPETENSI, KEPUASAN KERJA DAN MOTIVASI TERHADAP KINERJA PEGAWAI PADA KANTOR KECAMATAN KURIPAN
}

\author{
Muhammad Rudiansyah \\ STIMI Banjarmasin \\ Jl. Kuripan No. 26 Banjarmasin \\ Email: rudibanper@gmail.com
}

\begin{abstract}
The purpose of this study was to determine the effect of competence, job satisfaction and motivation on employee performance at the Kuripan sub-district office, Barito Kuala district either simultaneously or partially, then also to determine which independent variables had the most dominant influence on employee performance. The population in this study were all employees of the Kuripan district office. The sample of this research was 23 people who were taken using census technique (saturated sampling). The data analysis technique used multiple linear regression through version 25 of the SPSS (Statistical Package for the Social Science) computer application. Based on the results of this study, it is known that (1) simultaneously competence, job satisfaction and motivation have a significant effect on employee performance; (2) partially there are only two variables, namely job satisfaction and motivation which have a significant effect on performance; (3) the variable of motivation which has a dominant effect on employee performance.
\end{abstract}

Keywords: competence, job satisfaction, motivation, employee performance

Abstrak - Tujuan dari penelitian ini adalah untuk mengetahui pengaruh kompetensi, kepuasan kerja dan motivasi terhadap kinerja pegawai pada kantor kecamatan kuripan kabupaten Barito Kuala baik secara simultan maupun parsial kemudian juga untuk mengetahui variabel bebas manakah yang paling dominan berpengaruh terhadap kinerja pegawai. Populasi dalam penelitian in adalah seluruh pegawai kantor kecamatan kuripan. Sampel penelitian ini sebanyak 23 orang yang diambil menggunakan teknik sensus (sampling jenuh). Teknik analisis data menggunakan regresi linear berganda melalui aplikasi komputer SPSS (Statistical Package for the Social Science) versi 25. Berdasarkan hasil penelitian ini diketahui bahwa (1) secara simultan kompetensi, kepuasan kerja dan motivasi berpengaruh signifikan terhadap kinerja pegawai; (2) secara parsial hanya dua variabel yaitu kepuasan kerja dan motivasi yang berpengaruh signifikan terhadap kinerja; (3) variabel motivasi yang berpengaruh dominan terhadap kinerja pegawai.

Kata Kunci : kompetensi, kepuasan kerja, motivasi, kinerja pegawai

\section{PENDAHULUAN}

Ketentuan terhadap pemerintah yang jujur dan lepas dari korupsi, kolusi dan nepotisme (KKN) demi memperoleh harapan yang banyak dari masyarakat serta agar terciptanya kondisi usaha yang mendukung akan perkembangan investasi demi mendesak cepat kemajuan dan perkembangan ekonomi maupun mikro ekonomi dituntut adanya prosedur yang bagus dan didukung oleh sumber daya manusia dalam hal ini pegawai negeri sipil yang bermutu dan mempunyai kompetensi di bidang pekerjaan.

Upaya peningkatan kinerja pegawai salah satunya adalah menegakkan dan mengukuhkan mindset aparat birokrasi pada prinsip-prinsip moral yang harus ditegakkan keadaan ini merupakan sebuah keharusan bagi aparat pemerintah akan makin menambah kesadaran akan moralitas, memandang mereka pelaku utama dalam proses birokrasi di pemerintahan sumber daya manusia dalam hal ini para pegawai dituntut agar bisa terus bekerja dengan produktif yang diukur melalui pencapaian target pencapaian kinerja organisasi.

Kinerja (performance) selaku gambaran mengenai tingkat pencapaian penerapan suatu kegiatan/program/kebijakan seraya mewujudkan sasaran, tujuan, visi dan misi organisasi yang tertuang dalam perencanaan strategi (Strategic Planning) suatu organisasi. Menurut Mahsun (2006) istilah kinerja kerap juga digunakan demi menyebutkan prestasi atau tingkat keberhasilan individu maupun kelompok individu. Kinerja bisa diketahui jika individu atau kelompok tersebut mempunyai kriteria keberhasilan yang telah ditetapkan sebelumnya. Kriteria keberhasilan ini berupa tujuan-tujuan atau targettarget tertentu yang hendak dicapai. Tanpa ada tujuan atau target, kinerja seseorang atau organisasi tidak mungkin dapat diketahui karena tidak ada tolak ukurnya. 
Kompetensi menurut Spencer and Spencer (dalam Dharma 2003:111) adalah karakteristik dasar yang dimiliki seseorang yang berkaitan dengan kinerja orang tersebut dalam pekerjaannya. Karakteristik dasar tersebut berupa pengetahuan, kemampuan, keterampilan, perilaku dan konsep diri yang dimiliki seseorang yang dapat digunakan untuk menyelesaikan suatu jenis tugas atau jabatan tertentu yang menjadi pekerjaannya. Jadi kompetensi sumber daya manusia dalam suatu organisasi seharusnya disesuaikan dengan keperluan organisasi yang bersangkutan agar efektif dan efisien dalam menunjang tercapainya tujuan organisasi.

Kepuasan kerja merupakan sikap (positif) tenaga kerja terhadap pekerjaannya, yang timbul berdasarkan penilaian terhadap situasi kerja. Penilaian tersebut dapat dilakukan terhadap salah satu pekerjaannya, penilaian dilakukan sebagai rasa menghargai dalam mencapai salah satu nilai-nilai penting dalam pekerjaan. Pegawai atau karyawan yang puas lebih menyukai situasi kerjanya dari pada tidak menyukainya. Sedangkan nilai-nilai pekerjaan merupakan tujuan-tujuan yang ingin dicapai ialah nilai-nilai pekerjaan yang dianggap penting oleh individu. Dikatakan selanjutnya bahwa nilai-nilai pekerjaan harus sesuai atau membantu pemenuhan kebutuhan-kebutuhan dasar. Dikutip dari bukunya Siagian $(2001 ; 65)$ Kinerja karyawan atau pegawai dipengaruhi oleh beberapa faktor salah satunya yaitu kepuasan kerja. Upaya menigkatkan kompetensi dan kepuasan kerja pegawai terus dilakukan melalui program peningkatan kapasitas sumber daya aparatur namun upaya ini belum secara maksimal terealisasi.

Capaian kinerja organisasi pada Kantor Kecamatan Kuripan Kabupaten Barito Kuala tentunya masih banyak hal yang harus diperbaiki guna mendukung pencapaian kinerja organisasi yang optimal, melihat permasalahan dan latar belakang dan diperkuat dengan penelitian terdahulu maka penulis tertarik untuk melakukan penelitian tentang "Pengaruh Kompetensi, Kepuasan Kerja dan Motivasi terhadap Kinerja Pegawai pada Kantor Kecamatan Kuripan Kabupaten Barito Kuala”.

\section{KAJIAN PUSTAKA}

\section{Kompetensi}

Kompetensi adalah suatu keadaan yang berkaitan dengan kemampuan, pengetahuan atau wawasan, dan perilaku yang dijadikan suatu panduan selama melakukan tanggung jawab pekerjaan yang dikerjakan oleh pegawai. Kesuksesan yang didapat pegawai adalah hasil dari peningkatan kompetensi pegawai selama bekerja di tempat kerja.

Menurut pfeffer, dkk (2003:110) terdapat 5 karakteristik kompetensi yaitu:

a. Motif (Motives)

Motif adalah sesuatu dimana seseorang secara konsisten berfikir sehingga ia mekakukan tindakan.

b. Perangai (Traits)

Perangai adalah watak yang membuat orang untuk berprilaku atau bagaimana seseorang merespon sesuatu dengan cara tertentu.

\section{c. Konsep Diri (Self Concept)}

Konsep diri adalah sikap atau nilai yang diukur dengan tes responden untuk mengetahui apa yang dinilai baik oleh seseorang, apa yang pernah dilakukan atau apa yang ingin mereka lakukan.

\section{d. Pengetahuan (Knowledge)}

Pengetahuan adalah informasi yang dimiliki seseorang untuk bidang tertentu. Pengetahuan (Knowledge) merupakan kompetensi yang kompleks.

e. Kemampuan (Skills)

Skills adalah kemampuan untuk melaksanakan suatu tugas tertentu baik secara fisik maupun mental.

Dari penjelasan tersebut dapat disimpulkan bahwa tanggapan awal dari penerapan sistem kompetensi ini adalah menjadi jalan pemutus untuk memprediksikan keberhasilan kerja (kinerja). Akan tetapi dalam perkembangan ternyata sistem ini bisa diaplikasikan untuk banyak hal antara lain digunakan sebagai dasar dalam proses perencanaan, seleksi, suksesi, penilaian dan evaluasi kinerja, kompensasi, dan pengembangan sumber daya manusia lainnya.

\section{Kepuasan Kerja}

Setiap orang yang bekerja mengharapkan mencapai kepuasan dari tempatnya bekerja. Pada dasarnya kepuasan kerja merupakan hal yang bersifat individual oleh karena itu setiap individu akan memiliki tingkat kepuasan yang berbeda-beda sesuai dengan nilai-nilai yang berlaku dalam diri setiap individu. Semakin banyak aspek dalam pekerjaan yang sesuai dengan keinginan individu, maka semakin tinggi tingkat kepuasan yang dirasakan.

Menurut Kreitner dan Kinicki (2001:271) kepuasan kerja adalah "suatu efektifitas atau respon emosional terhadap berbagai espek pekerjaan". Davis dan Newstrom (1985:105) mendeskripsikan "kepuasan kerja adalah seperangkat perasaan pegawai tentang menyenangkan atau tidaknya pekerjaan 
mereka". Menurut Robbins (2003:78) kepuasan kerja adalah "sikap umum terhadap pekerjaan seseorang yang menunjukkan perbedaan antara jumlah penghargaan yang diterima pekerja dan jumlah yang mereka yakini seharusnya mereka terima".

Ada lima faktor yang dapat mempengaruhi kepuasan kerja (Kreitner dan Kinicki 2001:225) yaitu sebagai berikut:

a. Pemenuhan kebutuhan (Need Fulfillment)

Kepuasan ditentukan oleh tingkat karakteristik pekerjaan memberikan kesempatan pada individu untuk memenuhi kebutuhannya.

b. Perbedaan (Discrepancies)

Kepuasan merupakan suatu hasil memenuhi harapan. Pemenuhan harapan mencerminkan perbedaan antara apa yang diharapkan dan apa yang diperoleh individu dari pekerjaannya. Bila harapan lebih besar dari apa yang diterima, orang akan tidak puas. Sebaliknya individu akan puas bila menerima manfaat diatas harapan.

c. Pencapaian Nilai (Value Attainment)

Kepuasan merupakan hasil dari persepsi pekerjaan memberikan pemenuhan nilai kerja individual yang penting.

d. Keadilan (Equity)

Kepuasan merupakan fungsi dari seberapa adil individu diperlukan di tempat kerja.

e. Komponen genetik (Genetic components)

Kepuasan kerja merupakan fungsi sifat pribadi dan faktor genetik. Hal ini menyiratkan perbedaan sifat individu mempunyai arti penting untuk menjelaskan kepuasan kerja disamping karakteristik lingkungan pekerjaan.

\section{Motivasi}

Motivasi adalah Pemberian daya penggerak yang menciptakan kegairahan kerja seseorang, agar mereka mau bekerjasama, bekerja efektif dan terintegrasi dengan segala dan upayanya untuk mencapai kepuasan (Melayu S.P Hasibuan, 2006:2019).

Menurut Sedarmayanti (2009:233) indikator motivasi yaitu:

1. Gaji

2. Supervisi

3. Kebijakan dan Adminstrasi

4. Hubungan Kerja

5. Kondisi Kerja

6. Pekerjaan itu sendiri

7. Peluang untuk maju
8. Pengakuan dan penghargaan

9. Keberhasilan

10. Tanggung Jawab

\section{Kinerja}

Setiap individu yang bekerja dan organisasi yang beroperasi pasti beroriantasi pada visi, tujuan dan sasaran tertentu. Organisasi pasti mengetahui apa yang didapatkan pada customer atau klien selama waktu tertentu sebagaimana tergambar dalam visi organisasinya, dan individu juga seharusnya tahu apa yang menjadikan sasaran atau terget dari pekerjaannya semala kurun waktu tertentu.

Sedangkan menurut Prawirosentono (2008:27), kinerja dapat dinilai dan diukur dengan indikator yaitu :

a. Efektifitas yaitu bila tujuan kelompok dapat dicapai dengan kebutuhan yang direncakan.

b. Tanggung jawab merupakan bagian yang tak terpisahkan atau sebagai akibat kepemilikan wewenang.

c. Disiplin yaitu taat padahukum dan aturan yang berlaku. Disiplin karyawan adalah ketaatan yang bersangkutan dalam menghormati perjanjian kerja dengan perusahaan.

d. Inisiatif berkaitan dengan daya pikir, kreatifitas dalam bentuk suatu ide yang berkaitan tujuan perusahaan. Sifat inisiatif sebaiknya mendapatkan perhatian atau tanggapan perusahaan dan atasan yang baik. Dengan perkataan lain inisiatif keryawan merupakan daya dorong kemajuan yang akhirnya akan mempengaruhi kinerja karyawan.

Berdasarkan penjelasan kinerja diatas, dapat disimpulkan bahwa kinerja merupakan hasil kerja baik itu secara kualitas maupun kuantitas yang telah dicapai pegawai, dalam menjalankan tugas-tugasnya sesuai dengan tanggung jawab yang diberikan organisasi, dan hasil kerjanya tersebut disesuaikan dengan hasil kerja yang diharapkan organisasi, melalui kriteria-kriteria atau standar kinerja pegawai yang berlaku dalam organisasi.

\section{Kerangka Konseptual}

Berdasarkan pada hasil penelitian terdahulu, maka kerangka konsep penelitian digambarkan dibawah ini : 


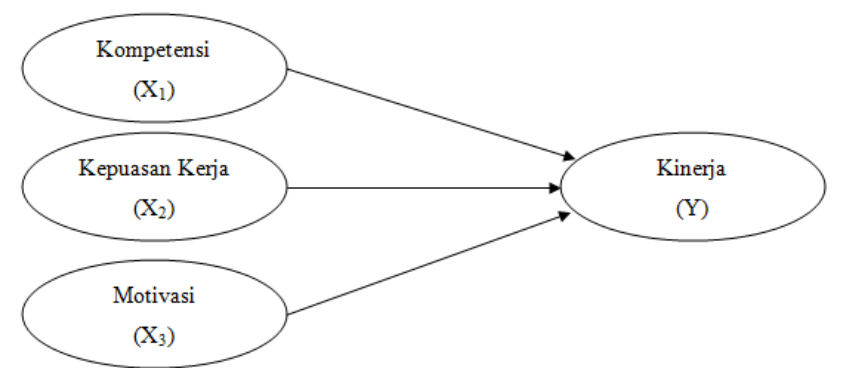

Gambar 1 Kerangka Konseptual Penelitian

\section{Hipotesis Penelitian}

Berdasarkan rumusan masalah, tinjauan pustaka dan kerangka konseptual yang telah dikemukakan, maka dapat dirumuskan hipotesis sebagai berikut:

1. Diduga variabel kompetensi, kepuasan kerja dan motivasi secara simultan berpengaruh terhadap kinerja pegawai pada Kantor Kecamatan Kuripan Kabupaten Barito Kuala.

2. Diduga variabel kompetensi, kepuasan kerja dan motivasi secara parsial berpengaruh terhadap kinerja pegawai pada Kantor Kecamatan Kuripan Kabupaten Barito Kuala.

3. Diduga variabel Motivasi berpengaruh dominan terhadap kinerja pegawai pada Kantor Kecamatan Kuripan Kabupaten Barito Kuala.

\section{METODE PENELITIAN}

\section{Jenis dan Sumber Data}

Jenis data yang diperlukan dalam penelitian ini terdiri dari :

1. Data Primer

Data primer adalah merupakan data yang diperoleh secara langsung dari responden dengan menggunakan daftar koesioner terstruktur yang berisikan bagaimana tanggapan responden terhadap pertanyaan-pertanyaan yang berhubungan dengan kompetensi,kepuasan kerja dan motivasi secara simultan dan parsial berpengaruh terhadap kinerja pegawai.

\section{Data Sekunder}

Data sekunder adalah sebagai pelengkap guna menunjang data primer, yakni sejarah perusahaan, struktur organisasi serta sarana prasarana.

\section{Instrumen Penelitian}

Dimaksud Instrumen penelitian adalah alat yang digunakan untuk pengukuran terhadap variabelvariabel yang diteliti. Mengingat gejala-gejala yang ada berkaitan dengan kompetensi,kepuasan kerja dan motivasi berpengaruh terhadap kinerja pegawai lebih banyak menunjukkan suatu sikap, maka pengukuran menggunakan Skala Likert yaitu skor yang digunakan 1 s.d. 5 yang diterapkan secara bervariasi menurut masing-masing kategori pertanyaan, sehingga masing-masing pertanyaan 5 pilihan saja.

Agar penelitian yang akan dilakukan menghasilkan data yang dapat dipercaya kebenarannya, maka instrument yang digunakan dalam penelitian harus terlebih dahulu diuji validitas dan reliabilitasnya.

\section{Populasi dan Sampel}

Adapun populasi dalam penelitian ini adalah pegawai pada Kantor Kecamatan Kuripan Kabupaten Barito Kuala yang berjumlah sebanyak 23 orang. Sedangkan sampel diambil dari seluruh jumlah populasi sebanyak 23 orang untuk dijadikan responden.

\section{Teknik Pengumpulan Data}

a. Observasi yaitu pengumpulan data dengan cara melakukan pengamatan secara langsung terhadap objek yang diteliti.

b. Interview yaitu pengumpulan data dengan cara mengadakan komunikasi secara langsung antara peneliti dengan seseorang atau lebih yang berada dalam objek yang diteliti sebagai sumber data.

c. Kuesioner yaitu seperangkat pertanyaan yang disusun untuk diajukan kepada responden yang berbentuk pertanyaan tertulis.

Data yang digunakan dalam penelitian ini adalah berupa data yang dikumpulkan atas 23 orang pegawai pada Kantor Kecamatan Kuripan Kabupaten Barito Kuala melalui penyampaian kuesioner kepada responden.

\section{Teknik Analisa Data}

Untuk membuktikan hipotesis yang telah diajukan, maka digunakan metode analisis sebagai berikut :

1. Analisa deskriptif adalah suatu analisis yang menggunakan statisik deskriptif, seperti rata-rata dan standar deviasi. Analisis ini digunakan untuk memperoleh gambaran mengenai kompetensi,kepuasan kerja dan motivasi berpengaruh terhadap kinerja pegawai pada Kantor Kecamatan Kuripan Kabupaten Barito Kuala.

2. Analisa regresi linier berganda yaitu suatu analisis yang bertujuan untuk menguji kompetensi,kepuasan kerja dan motivasi yang berpengaruh terhadap kinerja pegawai pada Kantor Kecamatan Kuripan Kabupaten Barito Kuala. 
Dengan menggunakan rumus regresi linear berganda yang dikutip dari buku Mulyono (2006 : 257) yaitu :

$$
Y=b 0+b 1 X 1+b 2 X 2+b 3 X 3+e
$$

Di mana :

$\mathrm{Y}=$ Kinerja

$\mathrm{X} 1=$ Kompetensi

$\mathrm{X} 2$ =Kepuasan Kerja

$\mathrm{X} 3$ = Motivasi

$\mathrm{e}=$ Pengganggu (error)

$\mathrm{a}=$ Konstanta

b1, b2, b3 = Koefisien regresi yang hendak diamati

Agar model regresi tersebut dapt digunakan untuk estimasi, maka harus memeuhi asumsi klasik, karena menurut Gujarati (1995:153), apabila asumsi klasik tidak dilanggar, maka estimator OLS (0rdinary Least Square ) akan BLUE (Best Linier Unbiased Estimator), artinya estimator tersebut bias dan mempunyai varians yang minimum.Asumsi klasik yang dianggap penting untuk diuji adalah Uji multikolinieritas, Uji heteroskedastisitas dan Uji autokorelasi.

3. Uji serempak ( Uji F) untuk pengujian hipotesis pertama

Uji ini digunakan untuk mengetahui apakah seluruh variabel bebasnya secara bersama-sama mempunyai pengaruh yang bermakna terhadap variabel terikat. Pengujian dilakukan dengan membandingkan nilai Fhitung dengan Ftabel pada derajat kesalahan $5 \%$ dalam arti $(\alpha=0.05)$. Apabila nilai Fhitung $\geq$ dari nilai Ftabel, maka berarti variabel bebasnya secara bersama-sama memberikan pengaruh yang bermakna terhadap variabel terikat atau hipotesis pertama sehingga dapat diterima.

4. Uji Parsial (Uji t) untuk pengujian hipotesis kedua

Uji ini adalah untuk mengetahui apakah pengaruh masing-masing variabel bebas terhadap variabel terikat apakah bermakna atau tidak. Pengujian dilakukan dengan membandingkan antara nilai thitung masing-masing variabel bebas dengan nilai ttabel dengan derajat kesalahan 5\% dalam arti $(\alpha$ $=0.05)$. Apabila nilai thitung $\geq$ ttabel, maka variabel bebasnya memberikan pengaruh bermakna terhadap variabel terikat.

Selanjutnya untuk melihat sumbangan variabel bebas dalam menerangkan variabel teriakat, dapat diketahui dari besarnya koefesien ditermenasi (R2). Jika R2 yang diproleh dari hasil perhitungan semakin besar (mendekati satu) maka dapat dikatakan bahwa sumbangan dari variabel bebas terhadap variabel terikat semakin besar, demikian juga sebaliknya.
Untuk melakukan perhitungan regresi linier berganda dan uji-uji tersebut digunakan bantuan kompoter dengan program SPSS Windows Versi 25.

\section{HASIL DAN PEMBAHASAN Hasil Uji Validitas}

Dari hasil menunjukkan bahwa untuk uji validitas instrumen variabel Kompetensi (X1) sebanyak 11 item pertanyaan semuanya valid, untuk instrumen penelitian variabel Kepuasan kerja (X2) sebanyak 11 item pertanyaan semuanya valid, untuk instrumen variabel Motivasi (X3) sebanyak 5 item semuanya valid, dan untuk variabel Kinerja sebanyak 10 item pertanyaan semuanya juga valid, karena nilai yang disyaratkan dari hasil korelasi $r>0,30$.

\section{Hasil Uji Reliabilitas}

Hasil uji reliabilitas koesioner terdapat nilai Cronbash's Alpha variable Kompetensi (X1) sebesar 0,945, Kepuasan kerja (X2) sebesar 0,971, Motivasi (X3) sebesar 0,876 dan Kinerja (Y) sebesar 0,950. Nilai Cronbah's Alpha semua kuesioner tersebut $>$ 0,60 . Dengan demikian kuesioner ini dikatakan reliabel dan dapat dipergunakan untuk mengumpulkan data penelitian.

\section{Hasil Uji Asumsi Klasik}

1. Uji Normalitas

Uji normalitas bertujuan untuk menguji apakah dalam model regresi, variabel residual memiliki distribusi normal atau tidak (Ghozali, 2001). Pengujian normalitas dilakukan dengan uji normalitas probability plot. Regresi memenuhi asumsi jika data menyebar disekitar garis diagnose dan mengikuti arah garis diagonal atau grafik histogramnya menunjukkan pola distribusi normal. Hasil dari uji normalitas dengan menggunakan program SPSS adalah sebagai berikut :

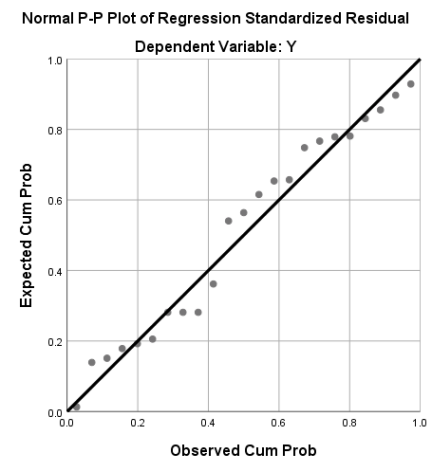

Kurva Normal P-plot

Pada Kurva Normal P-plot diatas dapat dilihat bahwa penyebaran titik-titik disekitar garis masih mengikuti garis lurus dan tidak melebar terlalu 
jauh. Maka dapat disimpulkan bahwa data penelitian berdistribusi normal.

2. Uji Multikolinearitas

Uji multikolinearitas bertujuan untuk menguji tingkat keeratan tingkat asomsi hubungan atau anrat variabel bebas (independen) melalui besaran koefisien korelasi. Untuk mendeteksi ada tidaknya multikolinearitas yaitu dengan melihat nilai VIF (Variance Inflation Faktor) dengan nilai tolerance. Model regresi dikatakan bebas dari multikolinearitas apabila nilai VIF $\leq 10$, dan nilai tolerance $\geq 0,1$ (Ghozali, 2001). Hasilnya uji multikolinearitas VIF dan tolerance dapat dilihat sebagai berikut:

Tabel 1 Hasil Uji Multikolinearitas

\begin{tabular}{lcc}
\hline \multicolumn{1}{c}{ Variabel } & Tolerance & VIF \\
\hline Kompetensi & 0,141 & 7,111 \\
\hline Kepuasan Kerja & 0,191 & 5,229 \\
\hline Motivasi & 0,146 & 6,836 \\
\hline
\end{tabular}

Sumber: Data diolah, 2020

Hasil perhitungan dari nilai tolerance Kompetensi adalah sebesar 0,141. Kepuasan Kerja adalah sebesar 0,191. dan Motivasi adalah sebesar 0,146 . Maka dapat disimpulkan bahwa tidak ada multikolinearitas dari nilai tolerance karena memiliki nilai lebih besar dari 0,10. Dilihat dari VIF Kompetensi, Kepuasan Kerja dan.Motivasi. Ketiganya menunjukkan tidak ada satu pun variabel independen yang memiliki nilai $\mathrm{VIF} \geq 0,1$.

3. Uji Heteros Kedastisitas

Uji heteroskedastisitas bertujuan untuk menguji sama atau tidak varians dari residual yang satu dengan observasi lain. Jika residual mempunyai varians yang sama, maka disebut terjadi heteroskedastisitas dan jika varians tidak sama disebut heteroskedastisitas jika pada scatterplot titiktitik hasil pengolahan data antara ZPRED (sumbu $\mathrm{X}=\mathrm{Y}$ hasil prediksi) dan SRESID (sumbu $\mathrm{Y}=\mathrm{Y}$ prediksi $\mathrm{Y}$ rill) menyebar dibawah atau diatas titik angka 0 pada sumbu $Y$ tidak mempunyai pola yang teratur (Ghozali, 2001). Hasil dari uji heteroskedastisitas adalah sebagai berikut :

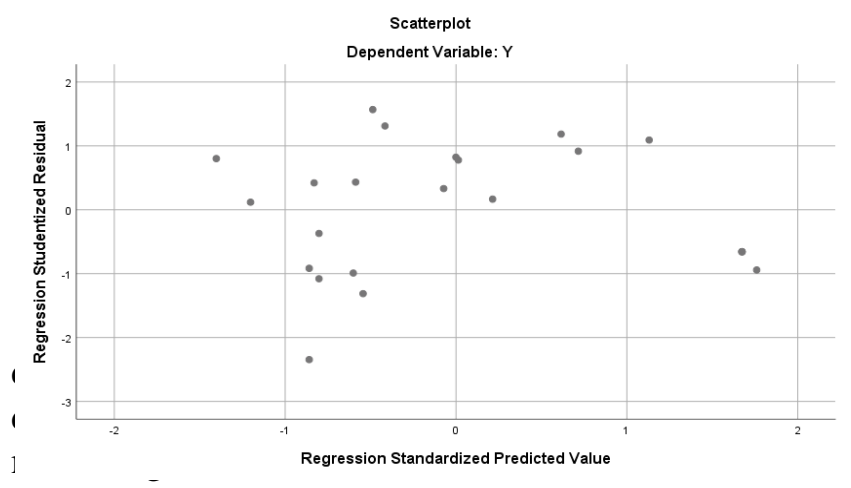

\section{Analisis Regresi Linier Berganda}

Rekapitulasi hasil uji regresi linier berganda dapat dilihat pada tabel sebagai berikut:

\section{Tabel 2}

Rekapitulasi Hasil Uji Regresi Linier Berganda

\begin{tabular}{lcccc}
\hline Variabel Bebas (X) & $\begin{array}{c}\text { Koefisien } \\
\text { Regresi }\end{array}$ & $\begin{array}{c}\text { Koefisien } \\
\text { Beta }\end{array}$ & T hitung & $\begin{array}{c}\text { Probabilitas } \\
\text { (Sig) }\end{array}$ \\
\hline Kompetensi (X1) & $-0,120$ & $-0,113$ & $-0,591$ & 0,561 \\
\hline Kepuasan Kerja (X2) & 0,419 & 0,459 & 2,801 & 0,011 \\
\hline Motivasi (X3) & 1,433 & 0,628 & 3,356 & 0,003 \\
\hline Konstanta & $-1,405$ & & & \\
F Hitung & 58,665 & & & \\
R & 0,950 & & & \\
$\mathbf{R}^{2}$ & 0,903 & & & \\
Adjusted R & 0,887 & & & \\
Sig. F & 0,000 & & & \\
SEE & 1,47565 & & & \\
\hline
\end{tabular}

Hasil Pengujian Hipotesis

Uji Hipotesis I

Berdasarkan hasil perhitungan pada tabel diatas dapat dilihat dengan pengujian hipotesis dengan $\mathrm{a}=$ $5 \%$ diperoleh nilai Ftabel $=3,49$. Sedangkan nilai $F$ hitung $=58,665$ jadi Fhitung $>\mathrm{F}$ tabel dan nilai probabilitas (sig) sebesar 0,000 lebih kecil dari 0,05. Dengan demikian bahwa hipotesis I terbukti ( diterima ) bahwa secara simultan/bersama-sama variabel Kompetensi, Kepuasan Kerja dan Motivasi mempunyai pengaruh signifikan terhadap Kinerja pegawai pada Kantor Kecamatan Kuripan Kabupaten Barito Kuala.

Angka R square atau R2 ( Koefisien Determenasi ) menunjukan besarnya kontribusi variable Kompetensi, Kepuasan Kerja dan Motivasi terhadap Kinerja pegawai Kantor Kecamatan Kuripan Kabupaten Barito Kuala.. Nilai R2 sebesar 0,903 berarti $90 \%$ Kinerja pegawai Kantor Kecamatan Kuripan Kabupaten Barito Kuala dipengaruhi oleh Kompetensi, Kepuasan Kerja dan Motivasi sedangkan sisanya $10 \%$ dipengaruhi oleh variable-variabel lain. Angka $\mathrm{R}$ adalah angka yang menunjukan keeratan hubungan antara variable bebas $(\mathrm{X})$ dengan variable terikat (Y). Nilai R sebesar 0,950 menunjukan bahwa antara variable bebas $(\mathrm{X})$ dengan variable terikat $(\mathrm{Y})$ terdapat hubungan yang cukup kuat dan searah.

Uji Hipotesis 2

Untuk menguji hipotesis kedua yang menyatakan bahwa diduga variable motivasi kerja berpengaruh dominan terhadap Kinerja pegawai pada Kantor Kecamatan Kuripan Kabupaten Barito Kuala.. Hasil regresi antara variable Kompetensi (X1) terhadap Kinerja pegawai sebagaimana dalam tabel diatas diperoleh nilai $\mathrm{t}$ hitung $=0,591$ sedangkan $\mathrm{t}$ tabel 2,079 sehingga H0 diterima dan Ha ditolak, maka 
dapat disimpulkan bahwa secara parsial variable Kompetensi tidak signifikan berpengaruh terhadap Kinerja pegawai pada Kantor Kecamatan Kuripan.

Hasil regresi antara variable Kepuasan kerja (X2) terhadap Kinerja sebagaimana dalam tabel diatas. menunjukan $\mathrm{t}$ hitung $=2,801$ sedangkan $\mathrm{t}$ tabel 2,079 sehingga Ha diterima dan Ho ditolak, dapat disimpulkan bahwa Kepuasan kerja mempunyai pengaruh positif dan signifikan terhadap Kinerja pegawai pada Kantor Kecamatan Kuripan Kabupaten Barito Kuala.

Hasil regresi antara variable Motivasi (X3) terhadap Kinerja pegawai sebagaimana dalam tabel diatas. menunjukan $\mathrm{t}$ hitung $=3,356$ sedangkan $\mathrm{t}$ tabel 2,079 sehingga $\mathrm{Ha}$ diterima dan H0 ditolak, maka dapat disimpulkan bahwa secara parsial variable Motivasi signifikan berpengaruh terhadap Kinerja Pegawai pada Kantor Kecamatan Kuripan Kabupaten Barito Kuala.

Dari hasil analisis tersebut tampak bahwa hipotesis 2 yang diajukan yakni Diduga variable Motivasi kerja berpengaruh dominan terhadap Kinerja pegawai pada Kantor Kecamatan Kuripan Kabupaten Barito Kuala terbukti (Diterima).

\section{Kesimpulan}

\section{KESIMPULAN DAN SARAN}

Berdasarkan hasil pengolahan data dan analisis serta pembahasan yang dilakukan pada penelitian ini, dapat disimpulkan sebagai berikut :

1. Berdasarkan hasil penelitian dengan uji statistik bahwa secara Simultan Kompetensi, Kepuasan Kerja dan Motivasi berpengaruh signifikan terhadap Kinerja pegawai pada Kantor Kecamatan Kuripan Kabupaten Barito Kuala.

2. Berdasrkan hasil penelitian dengan uji statistik bahwa secara parsial hanya dua variabel yaitu kepuasan kerja dan motivasi yang berpengaruh signifikan terhadap kinerja pegawai.

3. Berdasarkan hasil penelitian dengan uji statistik bahwa motivasi berpengaruh dominan terhadap kinerja pegawai pada kantor kecamatan kuripan kabupaten Barito Kuala.

\section{Saran-saran}

Berdasarkan kseimpulan tersebut diatas dapat diberikan saran sebagai berikut;

1. Kantor kecamatan kuripan kabupaten barito Kuala perlu meningkatkan kompetensi para pegawai agar kinerja pegawai tetap baik dan terus meningkat. Sedangkan kepuasan kerja dan motivasi yang diberikan perlu di pertahankan dan ditingkatkan.
2. Bagi peneliti berikutnya disarankan untuk mengambil sampel dan ruang lingkup penelitian yang lebih luas lagi, sehingga hasil yang didapatkan bisa lebih general sehingga bermanfaat untuk pengembangan ilmu pengetahuan.

\section{REFERENSI}

[1] Achmad.S. Rudy.2002. Sistem Manajemen Kinerja. Jakarta : Gramedia Pustaka Utama.

[2] Anwar Prabu Mangkunegara. 2014. Evaluasi Kinerja SDM. Bandung: PT. Reflika

[3] Arikunto, S. (2010). Prosedur Penelitian Suatu Pendekatan Praktek. Jakarta: Rineka Cipta.

[4] As'ad, M. (1995). Psikologi Industri. Jakarta: Liberty.

[5] Dharma. (2003). Perpustakaan dan Masyarakat, Cet. Ke-1. Jakarta: Yayasan Obor Indonesia.

[6] Dessler. Garry.2006. Manajemen Sumber Daya Manusia.Jilid 2. Edisi Ke-7 Jakarta: Benyamin Mollan and Prihalindo.

[7] Ghozali, I. (2016). Aplikasi Analisis Multivariat dengan Program SPSS. (Edisi Kedua). Semarang: Badan Penerbit Universitas Diponegoro.

[8] Kreitner, \& Kinicki, A. (2001). Perilaku Organisasi, Edisi Pertama, Alih Bahasa Erly Suandy. Jakarta: Selemba Empat.

[9] Mahsun, M. (2006). Pengukuran Kinerja Sektor Publik. Yogyakarta: Penerbit BPFE.

[10] Mitrani, A. (1995). Manajemen Sumber Daya Manusia Berdasarkan Kompetensi. Jakarta: Interenasa.

[11] Pfeffer, J., Soetjipto, B. W., \& Handoko, T. H. (2003). Paradigma Baru Manajemen Sumber Daya Manusia, Editor A. Usmara, Cetakan Keempat, Edisi Kedua. Yogyakarta: Penerbit Amara Books.

[12] Prawirosentono, S. (2008). Kebijakan Kinerja Karyawan. Yogyakarta: BPFE.

[13] Robbins, \& Stephen, P. (2003). Perilaku Organisasi (Alih Bahasa Drs. Benjamin Molan), Edisi Bahasa Indonesia. Klaten: PT Intan Sejati.

[14] Siagian, S. P. (2001). Teori dan Praktek Kepemimpinan. Jakarta: Penerbit Rineka Cipta.

[15] Sugiyono. (2008). Metode Penelitian Kuantitatif Kualitatif dan R\&D. Bandung: Alfabeta.

[16] Suwandhani. Deni. 2018. pengaruh Gaya Kepemimpinan Dan Motivasi Terhadap Kinerja karyawan. Jurnal Manajemen dan Kewirausahaan. Volume 9. Nomor 1 Januari 2018 